\title{
Air Force Thermal Battery Programs
}

\author{
David M. Ryan \\ AFRLPRPB, 1950 Fifth Street, W-PAFB, OHIO 45433-7251, ryandm@wl.wpafb.af.mil
}

\begin{abstract}
There are two thermal battery programs currently ongoing at WPAFB: a large thermal battery to supply emergency power for aircraft and an advanced weapons batter: The contractor for the large thermal battery is Eagle-Picher Technologies (EPT) of Joplin. Mo. The objective of this program is to develop a large thermal battery (ca. $100 \mathrm{lbs}$.) that can supply safe, reliable power for an aircraft during an emergency situation where the usual electrical power and hydraulic systems are no longer functioning. The technical challenges for this battery are to build a large, safe. reliable thermal battery that can activate in two seconds or less. generate 270V. and can supply two $56 \mathrm{HP}$ pulses of 30 seconds each and maintain a steady state power of $21 \mathrm{HP}$ for 19 minutes between the two pulses. The second program, the advanced weapons battery. is to being developed by SAFT. Cockeysviile. Md. The goal of this program is to develop a small, six-minute, $30 \mathrm{~V}$ thermal battery that can produce $88 \mathrm{Wh} / \mathrm{Kg}$.
\end{abstract}

\section{Thermal Batteries}

Thermal batteries are a type of reserve batter. That is. they can remain entirely inert until needed. When they are needed they can be activated and deliver full power within a very short time (usually 1 second or less). Thermal batteries have provided onboard power for weapons for over 45 years and during that time ther have developed an excellent reputation for safety and reliability in the field. Thermal batteries nominally produce about $45 \mathrm{Wh} / \mathrm{kg}$ and can function in a thermal environment that ranges from $-65^{\circ} \mathrm{F}$ to $165^{\circ} \mathrm{F}$. Thermal batteries have a demonstrated field storage life greater than 25 years. They contain no liquids and can be maintained at any attitude or altitude and are relied upon to not leak any toxic or corrosive materials in their environment. They contain no mercury. cadmium or lead and expended thermal batteries do not represent a major environmental hazard. Thermal batteries require no maintenance and have a relatively low cost of ownership.

Thermal batteries are composed of thermal cells that are compacted disks of finely ground metals and salts. The positive poles of the cells. the cathodes. are usually composed of highly oxidized materials such as $\mathrm{FeS}_{2}$. $\mathrm{CaCrO}_{4}, \mathrm{~V}_{2} \mathrm{O}_{5}$, etc. The negative poles. the anodes are usually composed of highly active and easily oxidizable metals such as $\mathrm{Li} . \mathrm{Ca}$. $\mathrm{Mg}$. etc. The electrolytes are compacted disks of finely divided salts. The saits are usually alkali or alkali metal saits and are mixtures because mixtures of salts usually melt at lower temperatures than the melting points of the pure components. When heat is applied to the mixtures the salts melt and the meited salts have a very low viscosity. They would flow like water if some binding material were not added to the electrolyte mixture. Then, when the salts melt. they immediately wet the binder (usually a clay or some other finely ground refractory material) and form a highly viscous, plastic material that does not significantly flow during the active life of the cell. The frozen electrolyte salts (that is. the salts before they are molten) are very poor ionic conductors. This is why inactivated thermal batteries are inert.

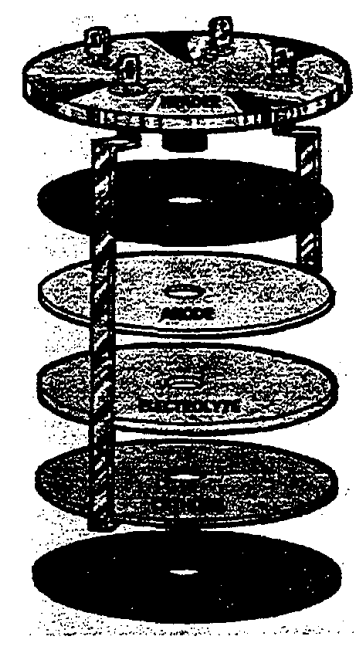

Figure 1. A model thermal batter: ${ }^{\text {a }}$

\footnotetext{
${ }^{\text {a }}$ Drawing courtery of Eagle-Picher. Ind.
}

U.S. Government work not protected by U.S. copyright 
Figure 1 shows a cartoon that accurately displays how a simple one-cell thermal battery is constructed. The anode disk is separated from the cathode disk by the electrolyte disk. These three disks constitute one complete thermal cell. Notice that the (+)-pole and the $(-)$-pole of the battery header is connected to the cathode and the anode. respectively, by two metallic conductors. Immediately outside of this assembly are two disks made of a pyrotechnic heat source. These disks will provide the heat that will cause the electrolyte salts to melt. They are usually composed of finely ground iron powder mixed with finely ground potassium perchlorate. This pyrotechnic mixture can be compacted in a neat disk just like the cell components were. Notice. just underneath and in the center of the header. a second pyrotechnic device. This is usually an electric match or a squib. When a small electric current is applied to the squib terminals on the top of the header it generates a flame that shoots down through the center holes in the cell components and ignites both pyrotechnic heat disks. This is why there were holes in the cell component disks.

The cells can be stacked upon each other with the heat pellets between each cell. The heat pellets are still electronically conductive after ignition. If the cells are stacked so the anode of one cell is facing the cathode of the next cell the effect is the same as wiring the cells together in series and the produced potential is multiplied. For example, if one cell could produce $1.8 \mathrm{~V}$ then a stack of 10 cells would produce $18 \mathrm{~V}$. Engineers have learned

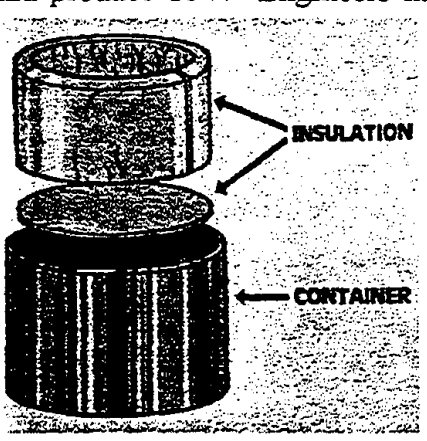

Figure 2. A typical battery container with insulation ${ }^{b}$.

how to stack the cells in parallel or in series to fabricate a battery that can produce almost any combination of potentials and currents. The stack and header can then be welded inside a steel can. Figure 2 shows a typical can containing suitable electrical and thermal insulation.

${ }^{b}$ Drawing courtesy of Eagle-Picher. inc.
When the cells and heat source have been snuggly welded into the can the result is a robust thermal battery that contains no liquids and keeps water from attacking the deliquescent salts.

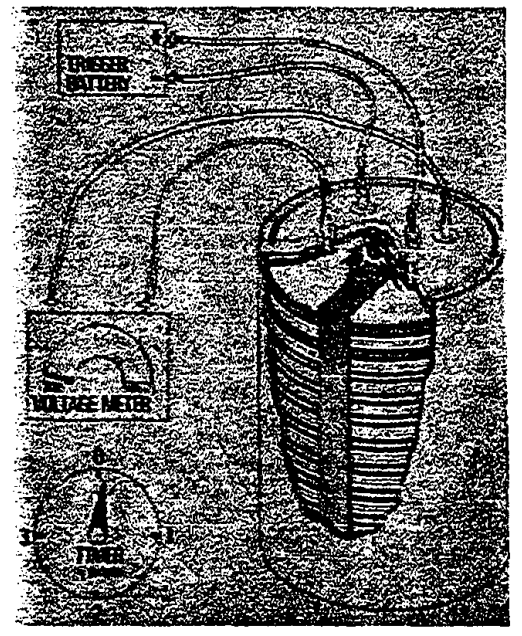

Figure 3 . The activation of a muiticell thermal battery.

Figure 3 shows a cutaway view of a typical thermal battery. Up at the top of the header, between the four terminals. some trigger device has just activated the electric match head. Notice that this battery does not have center holes in each cell. The heat source pellets are ignited by a fuse strip of pyrotechnic material that runs just under the match and along the entire side of the cell stack. The electric match ignites the fuse strip, which burns down the side of the cell igniting all of the other pyrotechnic pellets along the way. It can be seen that just a few miliseconds after activation there is practically no voltage registered on the voltmeter in the drawing.

In figure 4 the battery has been activated for nearly 500 milliseconds. the five upper heat pellets have burned and are beginning to cool. the next three pellets are burning now, and the flame-front of the fuse strips hasn't reached the lowest pellets yet. Notice that even after $1 / 2$ second after activation, considerable voltage is being measured on the voltmeter. Finally, figure 5 shows the battery one second after activation. The fuse strips and heat sources have all burned the cells have all melted and the voltmeter is registering full power. Depending on the size and design. thermal batteries can activate much faster than one second. 


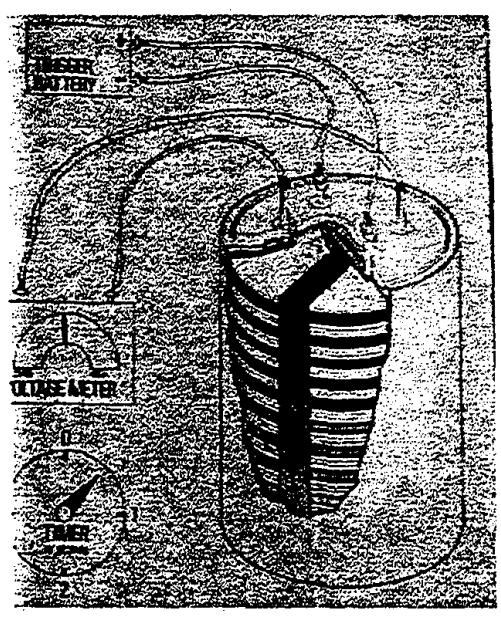

Figure 4. Thermal battery only partially activated.

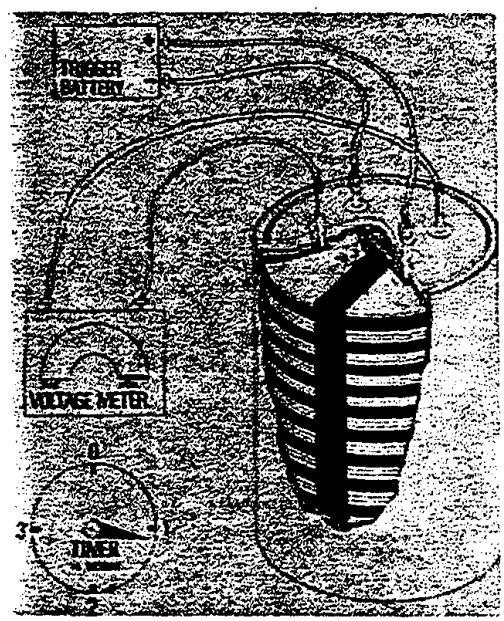

Figure 5. A cutaway view of a thermal battery that has been completely activated and is producing maximum power.

The battery can continue to produce current until either the heat leaks out of the battery. allowing the electrolyte salts to freeze. or the electroactive materials have all been consumed. The metallic case of the battery becomes hotter as the heat leaks out. The "skin" temperature of a thermal battery can exceed $300^{\circ} \mathrm{C}$. This process takes time and is usually not a problem with weapons batteries but this is a technological challenge for an aircraft battery. Some sort of insulated environment for the battery will probably be required. Furthermore, thermal batteries are primary batteries. That is, they can only be used one time. The pyrotechnic can only be burned once. Therefore, the expended thermal batteries onboard an aircraft will have to be replaced after they are used.

\section{New Programs}

There are currently two programs to develop new thermal battery technology ongoing at Air Force Research Lab at Wright-Patterson Air Force Base. One program is to develop a large thermal battery to supply emergency power for an aircraft. This battery must activate in less than 2 seconds and be prepared to produce $56 \mathrm{HP}$, at $270 \mathrm{~V}$. for 30 seconds. Immediately after the $15^{\text {th }}$ second. the required power will drop to $21 \mathrm{HP}$ and the power level will remain there for 19 minutes. Then the power level will jump back to $56 \mathrm{HP}$ for an additional 30 seconds. The battery will have a total twenty-minute life making it a relatively long life battery. It has been estimated that the battery weight must not exceed $100 \mathrm{lbs}$. to be practical for this application.

It is believed that a state-of-the-art (SOTA) thermal battery could produce $27 \mathrm{Wh} / \mathrm{lb}$. This would mean that a SOTA battery that could fulfill the requirements outlined above would weigh about $200 \mathrm{lbs}$. The challenge then is to develop a large thermal battery that can safely and reliable produce energy at twice the current SOTA rate. To accomplish this several new innovations are being tried. First a new anode is being tested. This is a new $\mathrm{Li}$ anode and it should increase the potential of each cell about $0.3 \mathrm{~V}$ This would allow the total number of cell to be reduced and the battery weight would drop from 195 lbs. to about $168 \mathrm{lbs}$. This would increase the energy density to about $31 \mathrm{Wh} / \mathrm{lb}$. A large portion of the stack weight is due to the heat source that is mostly iron powder. If a new lighter weight heat source could be found the weight could be reduced again. The new heat source we decided to try would lower the weight from over $40 \mathrm{lbs}$. to $11 \mathrm{lbs}$. This would lower the total battery weight to $139 \mathrm{lbs}$. and increase the energy density to 38 $\mathrm{Wh} / \mathrm{lb}$. The stainiess steel cases used to hold the cell stacks aiso make up a large portion of the weight. If a lighter weight material. such as some titanium alloy, could be used instead the battery weight would drop again. The battery weight would drop to $115 \mathrm{lbs}$ and the battery 
energy density would increase to $46 \mathrm{Wh} / \mathrm{lb}$. One final innovation is needed to finish the job. A new high-energy cathode is needed. The cathode chosen for this project would raise the cell voltage to about $4.1 \mathrm{~V}$. This would mean less cells and heat source pellets would be required and so the weight would drop again. The new battery weight would be about $76 \mathrm{lbs}$. This would cause the energy density to increase to $69 \mathrm{Wh} / \mathrm{lb}$. Therefore. its possible to succeed to fulfill the requirements as stated but all of the innovations are going to have to work.

The second project is a much smaller weapons battery. This battery is about the size and shape of a can of soft drink. It only has to function for six minutes but it needs to activate in 0.2 seconds. The required voltage is $25-34 \mathrm{~V}$ and the capacity is a little over $1.9 \mathrm{Ah}$. The maximum pulse power required is $900 \mathrm{~W}$. In this case the SOTA battery was calculated to weigh $1.334 \mathrm{~kg}$. contain 64 cells. and to produce $51 \mathrm{Wh} / \mathrm{kg}$. In this case a new proposed anode (different than the new anode proposed for the emergency aircraft battery) would decrease the required number of cells and the battery weight would drop to $1.236 \mathrm{~kg}$. This would increase the energy density to 56 $\mathrm{Wh} / \mathrm{kg}$. Using a titanium case would reduce the weight further and increase the energy density to $71 \mathrm{Wh} / \mathrm{kg}$. A new higher energy cathode is being explored and the estimated impact will be to lower the weight to $0.756 \mathrm{lbs}$. which will increase the energy density to $91 \mathrm{Wh} / \mathrm{kg}$. In this case not all of the innovations have to work to result in a practical battery

\section{Conclusion}

The Air Force has two programs to advance the state-of -the-art for thermal batteries. One program is to develop a large. safe and reliable thermal battery to suppiy emergency power for an aircraft. This project is applicable for both military and commercial aircraft. A second project is to develop a much smaller battery to supply onboard power for a weapon. In both projects new anode materials, new cathode materials. and new case materials are being tested. A search for a new heat source is going on. Progress for the weapons battery has been very good. A baseline battery has been designed which can fill all of the requirements. The advanced cathode material examined during this project has resulted in a cell that produces $245 \mathrm{Wh} / \mathrm{kg}$ relative to a $\mathrm{FeS}_{2}$ cell that produces about $165 \mathrm{Wh} / \mathrm{kg}$. 